Special Issue of the 6th International Congress \& Exhibition (APMAS2016), Maslak, Istanbul, Turkey, June 1-3, 2016

\title{
Theoretical and Experimental Study of a Cement Finish Mill
}

\author{
R. Magraoui* AND M. Temmar \\ University of Blida 1, Department of Mechanical Engineering, Structural Mechanics Research Laboratory, \\ BP 270 Blida, Algeria
}

\begin{abstract}
In this work, we study the dynamic behavior of a cement crusher. During its operation, several faults can occur. Our objective is to monitor the gear defect and other defects and make the necessary corrections. We model a part of the system: the gear transmission of the entire pinion-crown. We proceed to the simulation using a simulation program. Afterwards, we study the vibration behavior of the entire kinematic chain of the machine where we conduct programming vibrations of measurement points across all levels using vibration analysis software. The vibration measurements are realized with the aid of a data collector. The results of theoretical simulation are confronted with the analysis of experimental vibration measurements in order to determine the severity of mechanical faults and to establish an adequate vibratory prognosis.
\end{abstract}

DOI: 10.12693/APhysPolA.131.507

PACS/topics: 07.10.-h

\section{Introduction}

There are several gear defect detection techniques. The spectral analysis of vibration measurements allows pinpointing the problem. A reducer which has slight irregularities on the surfaces of each of the teeth will not cause a single signal. These slight irregularities are not considered defects. A larger notch, a cracked or chipped tooth, generate a single signal in the form of a pulse. The reducer's spectrum comprises combining deterministic signals from the gear intermeshing and random signals resulting from the interaction of the surfaces of the teeth, which contain the characteristic information of deterioration of gear teeth $[1,2]$.

In this work, we study a practical case of an axis parallel reducer with straight teeth, in an installation of a crusher control BK01. Our goal is to monitor the evolution of the anomalies and to establish corrections of mechanical defects. This work is accompanied by a vibration behavior study of the system. The results of theoretical simulation are confronted with experimental measures in order to determine the severity of mechanical faults and to establish an adequate vibratory prognosis $[3,4]$.

\section{Materials and equipment}

Several experiments were conducted on a cement plant. The crusher machine contains two reducers (Fig. 1). The first one is a Citroen reducer and the second one is composed of a spur gear connected to a ring (crown) $[5,6]$.

The main characteristics of the crusher machine are given in Table I.

In order to obtain the information needed, several points of vibration measurements are selected. In our

\footnotetext{
*corresponding author; e-mail: ma.graoui@hotmail.com
}

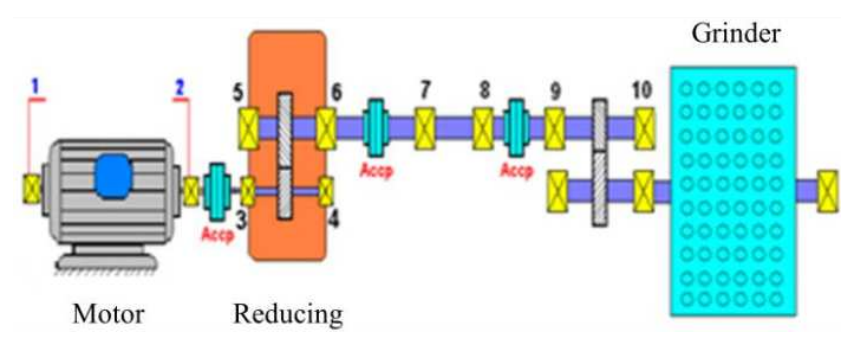

Fig. 1. Kinematic scheme and vibration measurement points.

case, we try to know the general state of the machine. It is therefore necessary to know the state of the bearings and the gears of the two gear trains, especially the second gear train. The modeling of the gear system was made in the SolidWorks program and meshed by the finite elements (Figs. 2 and 3). The planning of the measurement points was established by capturing all frequencies of interest and by following their changes in the horizontal, vertical and axial directions [7].

The measurement points on the bearings will serve to detect all the defects that may arise in the machine during its operation.

In addition, the dynamical behavior of the mechanical system is obtained by modeling the entire system in the SolidWorks program. The differential equations of motion are [2]:

$$
[M]\{\ddot{q}(t)\}+[C]\{\dot{q}(t)\}+[K]\{q(t)\}=\{F(t)\},
$$

where $[M],[C]$ and $[K]$ are respectively the mass, damping and stiffness matrices, $\ddot{q}(t), \dot{q}(t)$ and $q(t)$ are respectively the vectors of generalized acceleration, generalized velocities and generalized displacements, as functions of time $t, F(t)$ is the vector of the generalized forces.

\section{Results and discussion}

The simulation results of the modal analysis of the gearing system are summarized in Table II. 
TABLE I

Characteristics of the machine.

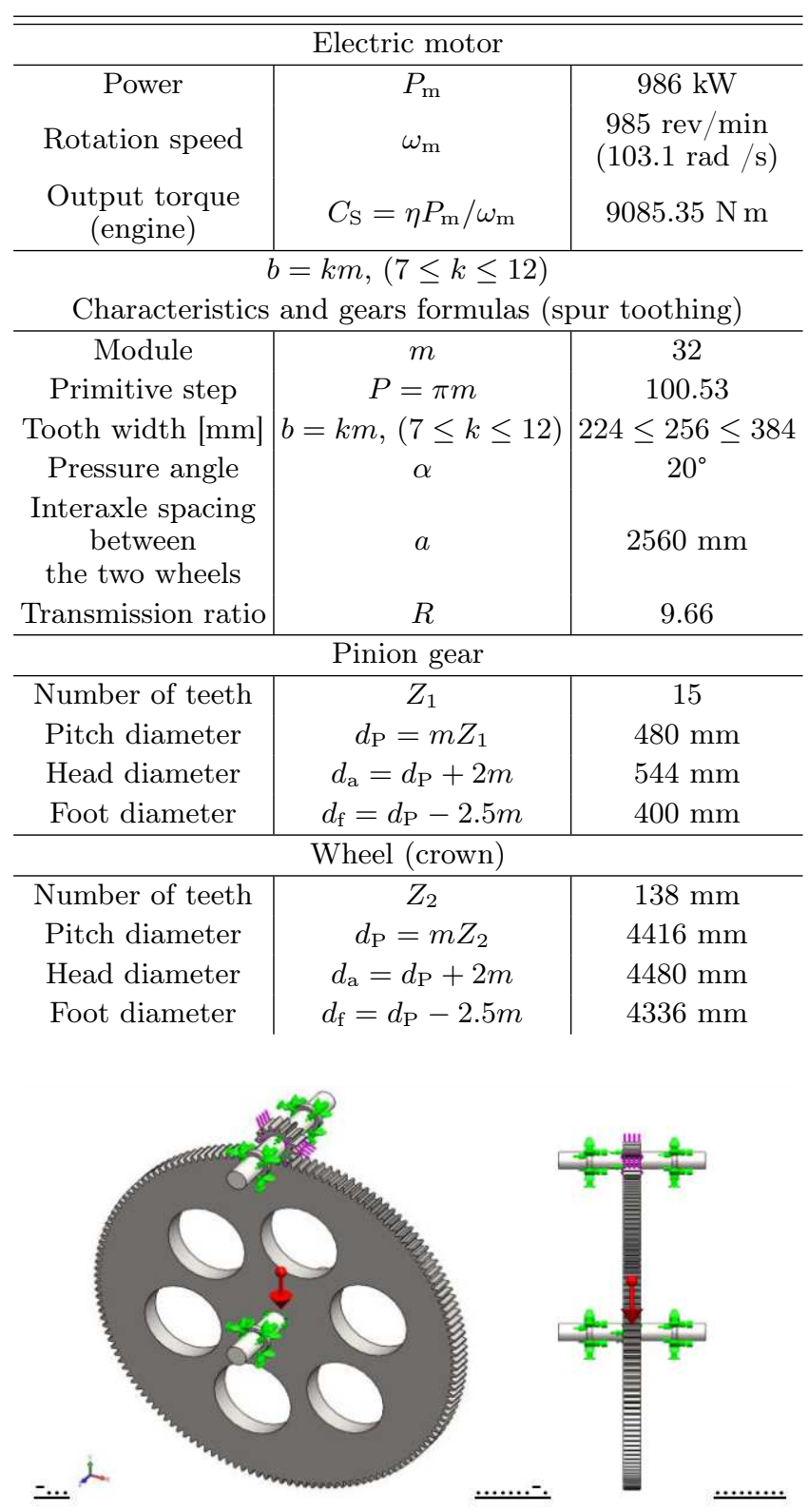

Fig. 2. Model of the gear system.

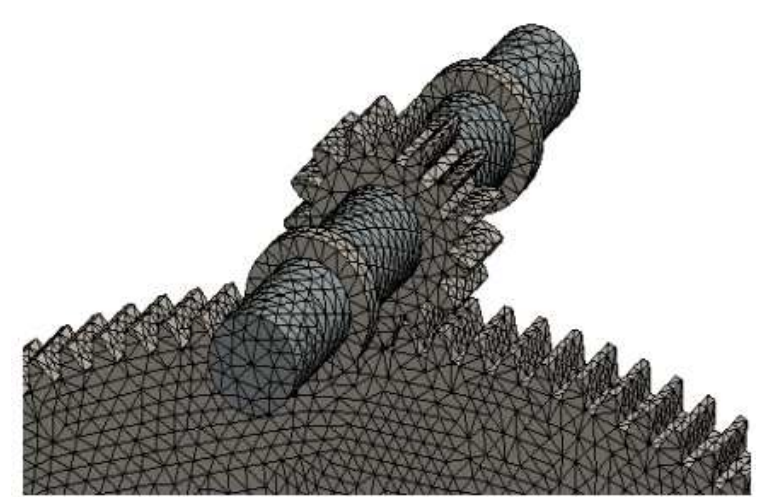

Fig. 3. Mesh using the finite elements.
TABLE II

Natural frequencies.

\begin{tabular}{c|c|c|c|c|c}
\hline \hline $\begin{array}{c}\text { No. } \\
\text { mode }\end{array}$ & $\begin{array}{c}\text { Natural } \\
\text { frequency } \\
{[\text { Rad/s] }}\end{array}$ & $\begin{array}{c}\text { Natural } \\
\text { frequency } \\
{[\mathrm{Hz}]}\end{array}$ & $\begin{array}{c}\text { No. } \\
\text { mode }\end{array}$ & $\begin{array}{c}\text { Natural } \\
\text { frequency } \\
{[\mathrm{Rad} / \mathrm{s}]}\end{array}$ & $\begin{array}{c}\text { Natural } \\
\text { frequency } \\
{[\mathrm{Hz}]}\end{array}$ \\
\hline 1 & 41.903 & 6.6691 & 11 & 1321.20 & 210.28 \\
2 & 166.38 & 26.48 & 12 & 1321.30 & 210.29 \\
3 & 166.56 & 26.509 & 13 & 1523.20 & 242.42 \\
4 & 219.36 & 34.912 & 14 & 1545.20 & 245.93 \\
5 & 315.02 & 50.137 & 15 & 1546.40 & 246.12 \\
6 & 315.08 & 50.147 & 16 & 1884.70 & 299.96 \\
7 & 729.30 & 116.07 & 17 & 1885.00 & 300.01 \\
8 & 737.89 & 117.44 & 18 & 2056.20 & 327.26 \\
9 & 1245.40 & 198.22 & 19 & 2056.50 & 327.30 \\
10 & 1245.70 & 198.26 & 20 & 2107.40 & 335.40
\end{tabular}

Because of the symmetry of the system, the natural frequencies are equal and the associated vibration modes are conjugated and symmetric.

For the lower natural frequencies, we have: (i) the first mode is the torsion mode (Fig. 4), (ii) the second and third bending modes are the most important.

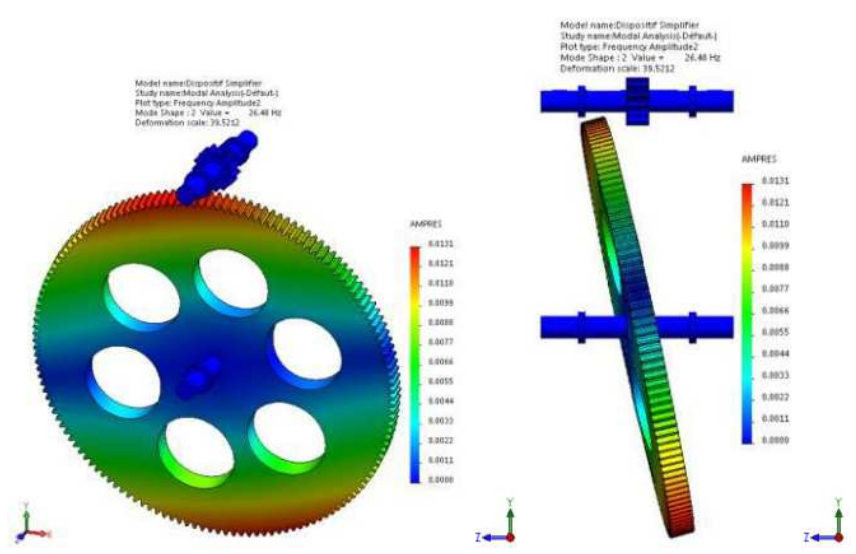

Fig. 4. First vibration mode of gear system.

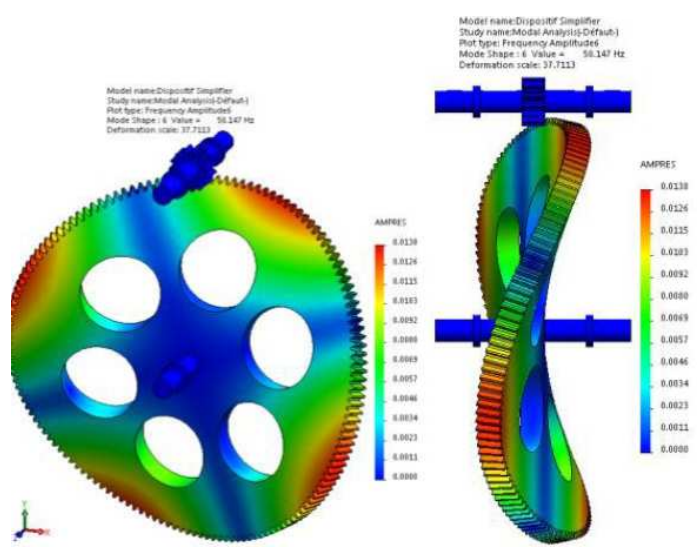

Fig. 5. Sixth vibration mode of gear system. 
The modes influence the dynamic behavior of the structure, especially the fifth and the sixth vibration modes (Fig. 5), which are nearest to the engaging system frequency of $48.75 \mathrm{~Hz}$, based on the results of vibration analysis given by the spectra.

The second and third modes converge towards the sixth harmonic of the system frequency of $48.75 \mathrm{~Hz}$, based on the results of vibration analysis given by the spectra.
The second and third modes converge towards the sixth harmonic of the fundamental frequency of rotation of the pinion gear which is $03.75 \mathrm{~Hz}$.

These modes are characterized by high participation of the mass ratio and are more dangerous than the higher modes. Low frequencies generate relatively simple mode forms, characterized by waves with lengths similar to object's size.

TABLE III

History of interventions and diagnostics.

\begin{tabular}{|c|c|c|c|c|c|c|}
\hline $\begin{array}{c}\text { Intervention } \\
\text { date }\end{array}$ & $\begin{array}{c}\text { Kind of } \\
\text { intervention }\end{array}$ & $\begin{array}{l}\text { Concerned } \\
\text { bearings } \\
\text { by spectrum } \\
\text { interpretation }\end{array}$ & $\begin{array}{c}\text { Spectrum } \\
\text { interpretation }\end{array}$ & $\begin{array}{c}\text { Overall vibration } \\
\text { level }[\mathrm{mm} / \mathrm{s}] \\
\text { of the bearing } \\
\text { No. } 9\end{array}$ & $\begin{array}{l}\text { Overall vibration } \\
\text { level }[\mathrm{mm} / \mathrm{s}] \\
\text { of the bearing } \\
\text { No. } 10\end{array}$ & Recommendations \\
\hline 25.08 .2015 & \multirow[t]{3}{*}{$\begin{array}{l}\text { Vibration } \\
\text { diagnostics } \\
\text { over entire } \\
\text { kinematic } \\
\text { chain or of } \\
\text { a specific } \\
\text { part }\end{array}$} & $\begin{array}{l}\text { No. } 8,9 \text { and } 10 \text {. Pre- } \\
\text { sence of a gearing } \\
\text { fault on the second } \\
\text { gear train at the out- } \\
\text { put of the command, } \\
\text { due to wear in an ad- } \\
\text { vanced state on the } \\
\text { flanks of the teeth of } \\
\text { the pinion and the } \\
\text { toothed ring. Fault } \\
\text { of alignment between } \\
\text { the bearings No. } 9 \\
\text { and } 10 . \\
\text { nment between the } \\
\text { two shafts of lines, } \\
\text { carried by the bea- } \\
\text { rings No. } 8 \text { and } 9\end{array}$ & $\begin{array}{l}\text { Bearings defects } \\
\text { in the the Citroen } \\
\text { reducer No. } 1 . \\
\text { Defect (failure ) } \\
\text { chipping on the } \\
\text { sides of the teeth } \\
\text { of the attack of } \\
\text { this reduction } \\
\text { gear }\end{array}$ & 03.75 & 05.73 & $\begin{array}{l}\text { Change the ge- } \\
\text { arbox bearings } \\
\text { No. 1. Check } \\
\text { of the clearance } \\
\text { between the sides } \\
\text { of the teeth of } \\
\text { the pinion gear } \\
\text { and the gear of } \\
\text { the gearbox No. } 1 \\
\text { and No. } 2 \text { of the } \\
\text { output of the } \\
\text { command Bro- } \\
\text { yeur. Correction } \\
\text { of alignment of } \\
\text { the two con- } \\
\text { nected line shafts } \\
\text { carried by the } \\
\text { bearings No. } 8 \\
\text { and } 10\end{array}$ \\
\hline 22.10 .2015 & & $\begin{array}{l}\text { No. } 10 . \quad \text { Meshing } \\
\text { fault in gear No. } 2\end{array}$ & $\begin{array}{l}\text { At the output of } \\
\text { the command, } \\
\text { and in parti- } \\
\text { cular on the } \\
\text { bearing No. 10, } \\
\text { the overall level } \\
\text { of vibrations is } \\
\text { amplified }\end{array}$ & 05.01 & 13.90 & $\begin{array}{l}\text { Considerable im- } \\
\text { provement in the } \\
\text { level of vibrati- } \\
\text { ons in the reducer } \\
\text { No. } 1\end{array}$ \\
\hline 19.11 .2015 & & $\begin{array}{l}\text { Reducer No. } 2 \text {. Ad- } \\
\text { vanced usury on the } \\
\text { profile of the flanks } \\
\text { of the pinion and the } \\
\text { toothed ring }\end{array}$ & & 04.32 & 13.10 & \\
\hline
\end{tabular}

According to on-site intervention based on different calculations and spectral interpretations, we have (see Table III and Figs. 6-10):

- Presence of a gearing fault on the reducer No. 1, where the gearing frequency is $428.68 \mathrm{~Hz}$.

- Presence of a gearing fault on the reducer No. 1, where the gearing frequency is $428.7 \mathrm{~Hz}$ and a frequency modulation of $16.8 \mathrm{~Hz}$. This frequency is related to the rotation base frequency of the drive pinion of the gear unit.

- Presence of a meshing fault on the gearbox No. 2, where the gearing frequency is $47.34 \mathrm{~Hz}$ with a modulation frequency of $3.12 \mathrm{~Hz}$, concerning basis to the basis of gear pinion on the second harmonic of $94.67 \mathrm{~Hz}$,

- Presence of bearing fault on the reducer No. 1, where the gearing frequency is $47.31 \mathrm{~Hz}$. 


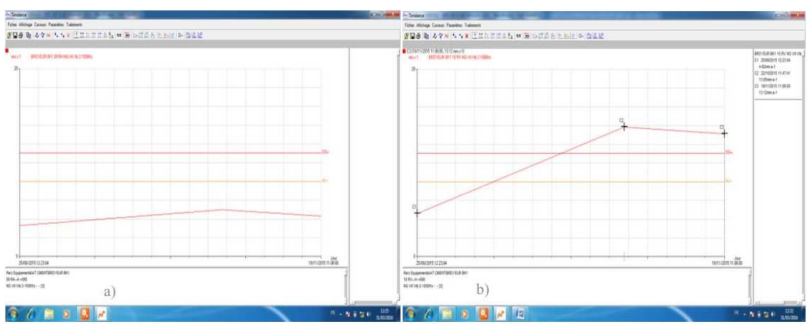

Fig. 6. Vibratory trend of BK 01 on the landing (a) No. 9 in the horizontal direction, (b) No. 10 in the vertical direction.

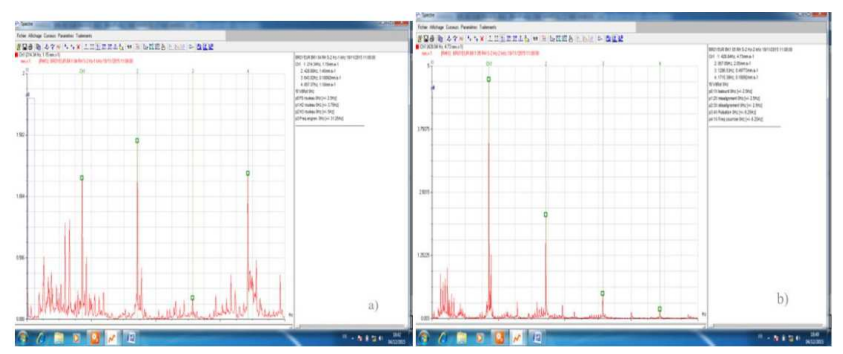

Fig. 7. Spectrum taken on the bearing (on the October $19^{t h}, 2015$ ) (a) No. 4 in the horizontal direction, (b) No. 5 in the horizontal direction.

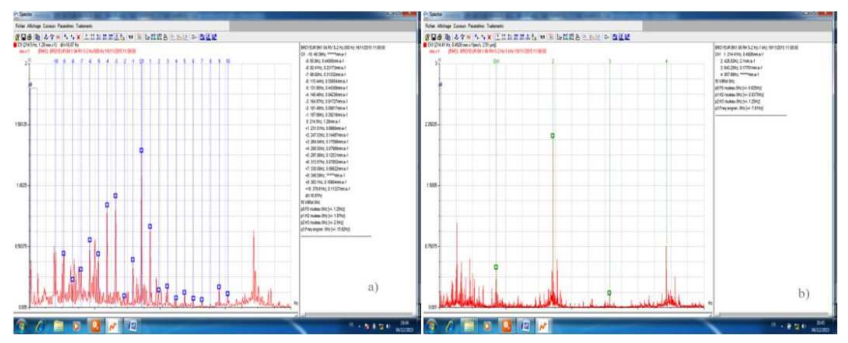

Fig. 8. Spectrum of bearing (on November $19^{\text {th }}, 2015$ ) (a) No. 4 in the vertical direction, (b) No. 6 in the horizontal direction.

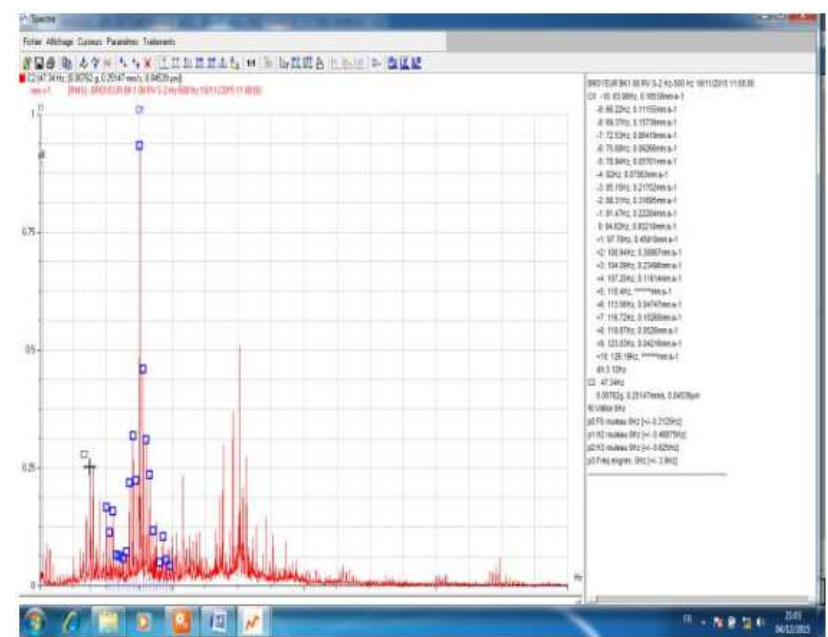

Fig. 9. Spectrum taken on the landing No. 8 in the vertical direction of BK01 (on November 19 ${ }^{t h}, 2015$ ).

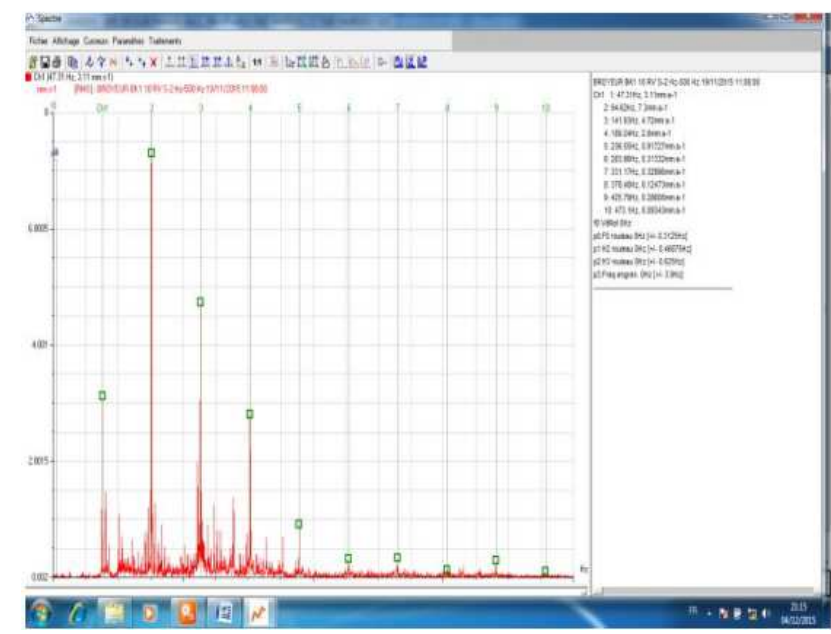

Fig. 10. Spectrum of bearing No. 10 in the vertical direction of BK01 (on November 19 ${ }^{\text {th }}, 2015$ ).

\section{Conclusions}

The treated machine requires vibration monitoring, which increases its availability. We were able to plan interventions for repairs. The installation had several mechanical faults, especially the engagement fault. This failure has affected several parts, like the bearings and couplings. These are important parts. During our study, some theoretical results were compared with the experimental results.

Due to the established vibratory prognosis, our study has allowed a cement factory to use the machine for four months.

\section{Acknowledgments}

This research has been supported by The Structural Mechanics Laboratory of the University of Blida 1. Project Number: J0300420120016.

\section{References}

[1] J. Mans, Framatome Diagnostic, Le diagnostic vibratoire au service de la Maintenance, Lyon 1992.

[2] P. Arqučs, Diagnostic prédictif de l'état des machines, Masson, 1996.

[3] Les défauts des machines in Les défauts des engrenages Encyclopédie pour formation en maintenance préventive, 1993.

[4] A. Rezig, M. Ouali, Adv. Product. Engin. Management 7, 237 (2012).

[5] M.Dougdag, M. Ouali, H. Boucherit, N.E. Titouche, M. Djaoui, Meccanica 47, 335 (2012). 